\title{
Holocene evolution of summer winds and marine productivity in the tropical Indian Ocean in response to insolation forcing: data-model comparison
}

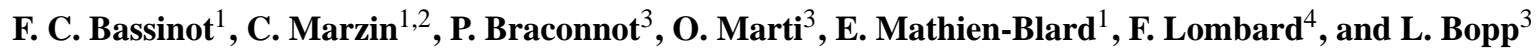 \\ ${ }^{1}$ LSCE/IPSL, UMR8112 - CEA/CNRS/UVSQ, Domaine du CNRS, bâtiment 12, 91198 Gif-sur-Yvette, France \\ ${ }^{2}$ Met Office Hadley Centre, FitzRoy Road, Exeter, EX1 3PB, UK \\ ${ }^{3}$ LSCE/IPSL, UMR8212 - laboratoire CEA/CNRS/UVSQ, Centre CEA-Saclay, Orme-les-Merisiers, \\ 91190 Gif-sur-Yvette, France \\ ${ }^{4}$ Université de la Méditerranée, UMR6535 - CNRS, Laboratoire d'Océanographie Physique et Biogéochimique, LOPB, \\ Campus de Luminy, Case 901, 13288 Marseille Cedex 9, France
}

Received: 3 January 2011 - Published in Clim. Past Discuss.: 3 February 2011

Revised: 26 May 2011 - Accepted: 17 June 2011 - Published: 28 July 2011

\begin{abstract}
The relative abundance of Globigerinoides bulloides was used to infer Holocene paleo-productivity changes on the Oman margin and at the southern tip of India. Today, the primary productivity at both sites reaches its maximum during the summer season, when monsoon winds result in local Eckman pumping, which brings more nutrients to the surface. On a millennium time-scale, however, the $\%$ G. bulloides records indicate an opposite evolution of paleo-productivity at these sites through the Holocene. The Oman Margin productivity was maximal at $\sim 9 \mathrm{ka}$ (boreal summer insolation maximum) and has decreased since then, suggesting a direct response to insolation forcing. On the contrary, the productivity at the southern tip of India was minimum at $\sim 9 \mathrm{ka}$, and strengthened towards the present.

Paleo-reconstructions of wind patterns, marine productivity and foraminifera assemblages were obtained using the IPSL-CM4 climate model coupled to the PISCES marine biogeochemical model and the FORAMCLIM ecophysiological model. These reconstructions are fully coherent with the marine core data. They confirm that the evolution of particulate export production and foraminifera assemblages at our two sites were directly linked with the strength of the upwelling. Model simulations at $9 \mathrm{ka}$ and $6 \mathrm{kaBP}$ show that the relative evolution between the two sites since the early Holocene can be explained by the weakening but also the southward shift of monsoon winds over the Arabian Sea during boreal summer.
\end{abstract}

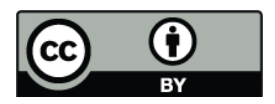

Correspondence to: F. C. Bassinot (bassinot@1sce.ipsl.fr)

\section{Introduction}

The northern tropical Indian Ocean and the surrounding lands are the location of a strong monsoon system, which has a profound impact on the socio-economy of one of the most densely populated areas of the world (Saha et al., 1979; Mooley et al., 1981; Mall et al., 2006). During the southwest (summer) monsoon, warm, moist air prevails, and a strong southwesterly wind jet runs diagonally across the Arabian Sea (Fig. 1a; Lee et al., 2000; Schott and McCreary, 2001). Reputedly, the southwest monsoon produces the strongest sustained oceanic winds outside the Southern Ocean. Winds during this period remain remarkably unidirectional, though magnitudes vary somewhat with time and space. This wind forcing contributes to the development of a clockwise upper ocean circulation pattern, with the South Equatorial Current and the East African Coast Current both supplying the northward flowing Somali Current in the western part of the Arabian Sea (Schott and McCreary, 2001). This Arabian Sea surface circulation reverses somewhat to an anti-clockwise pattern during the northeast (winter) monsoon, when sustained but weaker winds blow to the southwest (Fig. 1b).

The circulation at the tip of India is affected by a fresh water current from the Bay of Bengal (e.g., Durand et al., 2007). The fresh water is advected in winter by the westward flowing, North Equatorial Current (NEC). During the boreal summer, in response to the monsoon wind reversal, the flow in the NEC reverses and combines with a weakened Equatorial Counter-Current to form the South-West Monsoon Current. This affects the characteristics of the mixed layer depth by stratifying the surface ocean. The maximum

Published by Copernicus Publications on behalf of the European Geosciences Union. 

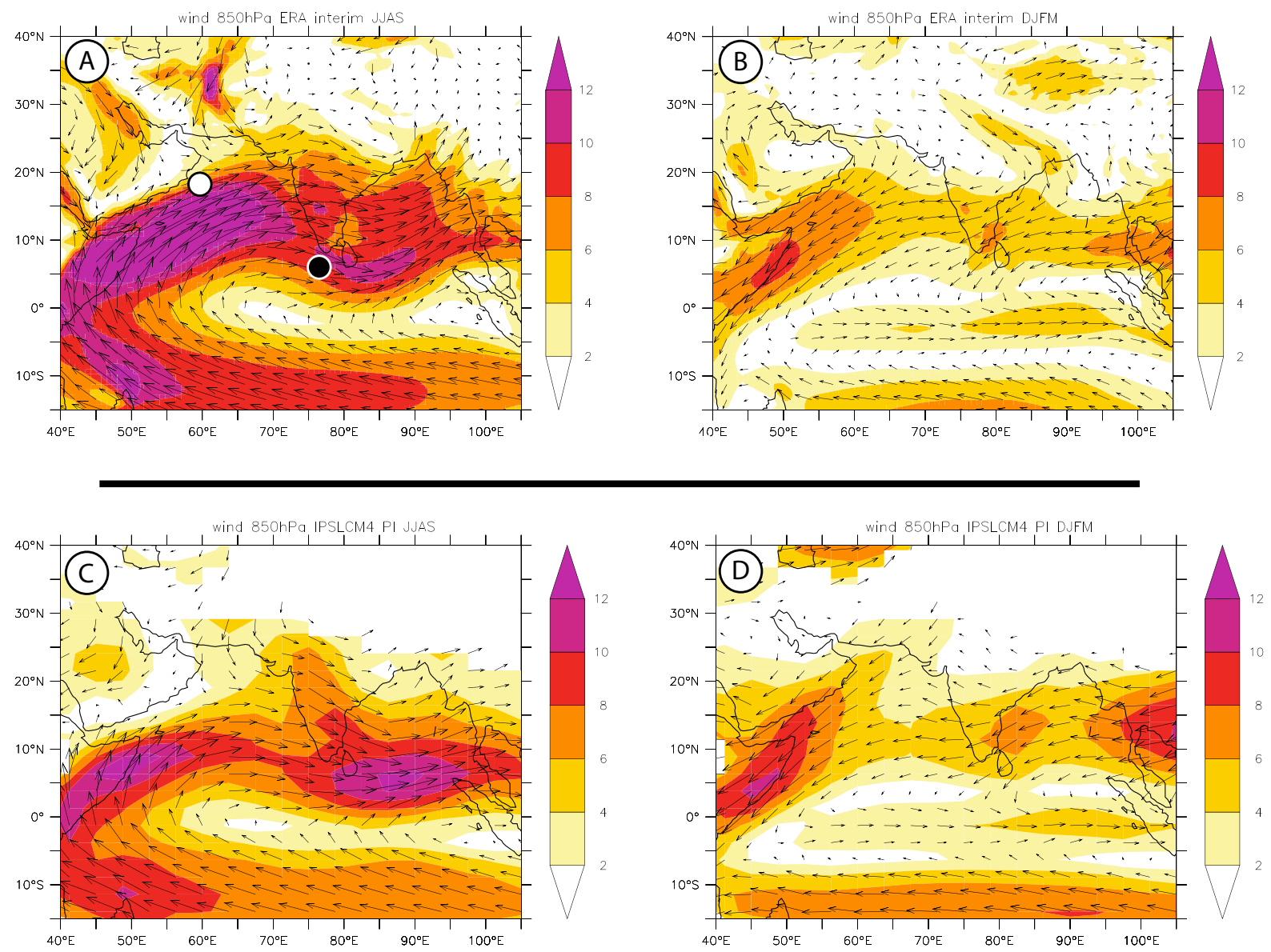

Fig. 1. (A) Summer (JJAS) wind patterns over the Arabian Sea. (B) Winter (DJFM) wind patterns over the Arabian Sea. (C) Summer wind pattern obtained from the Pre-industrial run of the IPSL-CM4 model. (D) Winter wind pattern obtained from the Pre-industrial run of the IPSL-CM4 model. Wind speed scales in $\mathrm{m} \mathrm{s}^{-1}$. The large, white dot and black dot on panel (A) indicate the location of ODP Site 723 and Core MD77-191, respectively.

surface temperature occurs in spring between the equator and the tip of India, prior to the monsoon onset (Rao and Sivakumar, 1999). These changes result either from local adjustments or from wave propagation. In March, the mixed layer depth is also deeper on both sides of the tip of India (Rao et al., 1989). Climate simulations indicate that salinity has a strong impact on the northern Indian Ocean stratification and surface warming and is likely to govern the date of onset of the summer monsoon (Masson et al., 2005).

In these Indian regions, climate modelling and forecasting are notoriously difficult. The Indian Monsoon is a particularly complex system, affected by a large array of periodic to semi-periodic forcings, regional to global in extent, with timescales ranging from inter-annual variations (i.e. El NiñoSouthern Oscillation-ENSO) to long-term $\left(10^{4}\right.$ to $\left.10^{5} \mathrm{yr}\right)$ orbital modulation of the solar insolation (i.e. Clemens et al., 1991; Prell and Kutzbach, 1992; Camberlin, 1997; Ashok et al., 2004; Kumar et al., 2006; Zhang and Delworth, 2006; Ihara et al., 2007; Braconnot et al., 2008). In order to address and unravel this complexity, meteorological and oceanographic instrumental records are too short, and one has to look for long, paleo-climatic records - such as those provided by marine sedimentary cores - to better understand the natural (pre-anthropic) variability of the Indian Monsoon system over a few thousand years. These data can be compared with model outputs for model benchmarking or, alternatively, to help address the complexity of paleo-data interpretation by identifying the potential climatic features at play (i.e. Overpeck et al., 1996; An et al., 2000; Liu et al., 2003; Braconnot et al., 2007a,b).

In this paper, we consider the monsoon evolution throughout the Holocene. Several studies combining proxy data and climate model simulations have shown that changes in insolation induced by the slow variation of the Earth's orbital parameters, and mainly precession, have been the major driver of the Holocene afro-asian monsoon evolution (COHMAP, 1988; Prell and Kutzbach, 1987; Joussaume et al., 1999; Liu et al., 2003). The orbital configuration that prevailed during the first half of the Holocene enhanced (reduced) seasonality in the Northern (Southern) Hemisphere. During boreal 
summer, the corresponding increase in the inter-hemispheric and the land-ocean temperature contrasts triggered the summer thermal lows over the Tibetan plateau and in the Sahara, which enhanced the monsoon flow from the moist tropical ocean into land. Regional patterns are, of course, superimposed on this large-scale scheme. These complex, regional changes result from the relative response of the different monsoon sub-systems to the insolation forcing, which includes various feedback mechanisms and the important role played by water column stratification on monsoon inception and intensity (Braconnot and Marti, 2003; Zhao et al., 2005; Ohgaito and Abe-Ouchi, 2007; Braconnot et al., 2008; Marzin and Braconnot, 2009a). There is a clear need to conduct data-model comparisons in order to better understand and simulate the relationship between the large-scale variations in the monsoon flow and the characteristics of the water column in different areas of the Indian Ocean.

Seasonal upwellings that develop in various parts of the Indian Ocean provide key locations in which sedimentary records can provide estimates of wind forcing changes (i.e. Clemens et al., 1991; Anderson and Prell, 1993; Emeis et al., 1995; Naidu and Malmgren, 1996; Clemens and Prell, 2003) that can be compared to model simulations. In this paper, we selected two zones: the upwelling area over the Oman Margin, and the upwelling area at the southern tip of India. Because of the different contexts in which these summer upwellings develop, the comparison of their respective paleo-productivity records has the potential to bring significant pieces of information about past changes in wind patterns over the northern Indian Ocean.

The aims of this paper are:

1. to compare the temporal evolution over the Holocene of monsoon-driven upwellings from the Oman margin and the southern tip of India based on sedimentary records of productivity changes;

2. to understand the relationship between the change in the ocean dynamics, marine biogeochemistry, foraminifera assemblages and monsoon, in order to refine the interpretation of the different ocean proxy records and produce key target points that can be used to evaluate the ability of climate models to reproduce monsoon fluctuations.

The paleo-reconstructions and the model simulations will be described in Sect. 2. Section 3 will look at the intimate relationship between productivity changes and monsoon evolution based on a thorough data-model comparison. In order to unravel properly the climatic signal embedded in our sedimentary records, the first part of Sect. 3 will be devoted to studying the coherency between model simulations and our sedimentary records. This will be done by analyzing outputs of the PISCES ocean biogeochemical model (Aumont and Bopp, 2006; Gehlen et al., 2007) forced with the mid-Holocene and the pre-industrial simulations obtained with the IPSL-CM4 climate model (Braconnot et al., 2008; Marzin and Braconnot, 2009a). Then, using the IPSL-CM4 and PISCES outputs, we will force a new eco-physiological model reproducing the growth of eight foraminifera species (FORAMCLIM model; Lombard et al, 2011) in order to better address model-data coherency. In the final part of this paper, we will combine data and model over the whole Holocene period to explore the climatic implications of environmental changes recorded at the two sites studied.

\section{Data and model}

\subsection{Paleo-reconstructions from sedimentary records}

\subsubsection{Core locations}

In the Arabian sea, monsoon-driven vertical mixing, coastal and open ocean upwellings show an important basin-wide spatio-temporal variability resulting in a large variety of phytoplankton blooms (Levy et al., 2007). On the western side of the Arabian Sea, strong upwelling cells develop along the Somalian and Arabian coasts during the summer monsoon, when the winds blow from the SW, parallel to the coast (Fig. 1a), resulting in a massive Eckman pumping. These upwellings can be clearly identified through satellite imaging of chlorophyll abundance (Fig. 2a). They weaken and stop during the winter season (Fig. 2b), when the winds reverse direction (Fig. 1b). On the opposite side of the Arabian Sea off the Indian margin, prevailing winds blow from the west during the summer season (Fig. 1a). The summer productivity increase along the western coast of India (Fig. 2a) is associated to a complex interplay of lateral advection, mixed-layer deepening and upwellings (i.e. Sharma, 1978; Shetye et al., 1990). At the southern tip of India, however, the summer increase in productivity is chiefly associated to the development of a seasonal upwelling (Levy et al., 2007).

In order to reconstruct paleo-productivity variations and address past changes in summer monsoon wind patterns and intensity over the Holocene, we selected two cores from these areas: Ocean Drilling Program (ODP) Site 723 $\left(19^{\circ} 03 \mathrm{~N}, 57^{\circ} 37 \mathrm{E}, 808 \mathrm{~m}\right.$ water depth) retrieved from the Oman margin, and core MD77-191 $\left(07^{\circ} 30^{\prime} \mathrm{N}, 76^{\circ} 43^{\prime} \mathrm{E}\right.$, $1254 \mathrm{~m}$ water depth) located at the southern tip of India (Table 1; Fig. 1a). The bioturbation smoothing is likely minimal at these sites, owing to the strong oxygen-minimum zone that develops at these water depths on the margins of the Arabian Sea. ODP Site 723 sedimentary record has been used in several studies devoted to reconstructing monsoon dynamics at millennial to orbital timescales (i.e. Anderson and Prell, 1993; Emeis et al., 1995; Naidu and Malgrem, 1995, 1996; Gupta et al., 2003). On orbital timescales, productivity records obtained in these studies clearly indicate that the strongest summer winds occurred in interglacial times, and lagged the times during which perihelion was aligned 

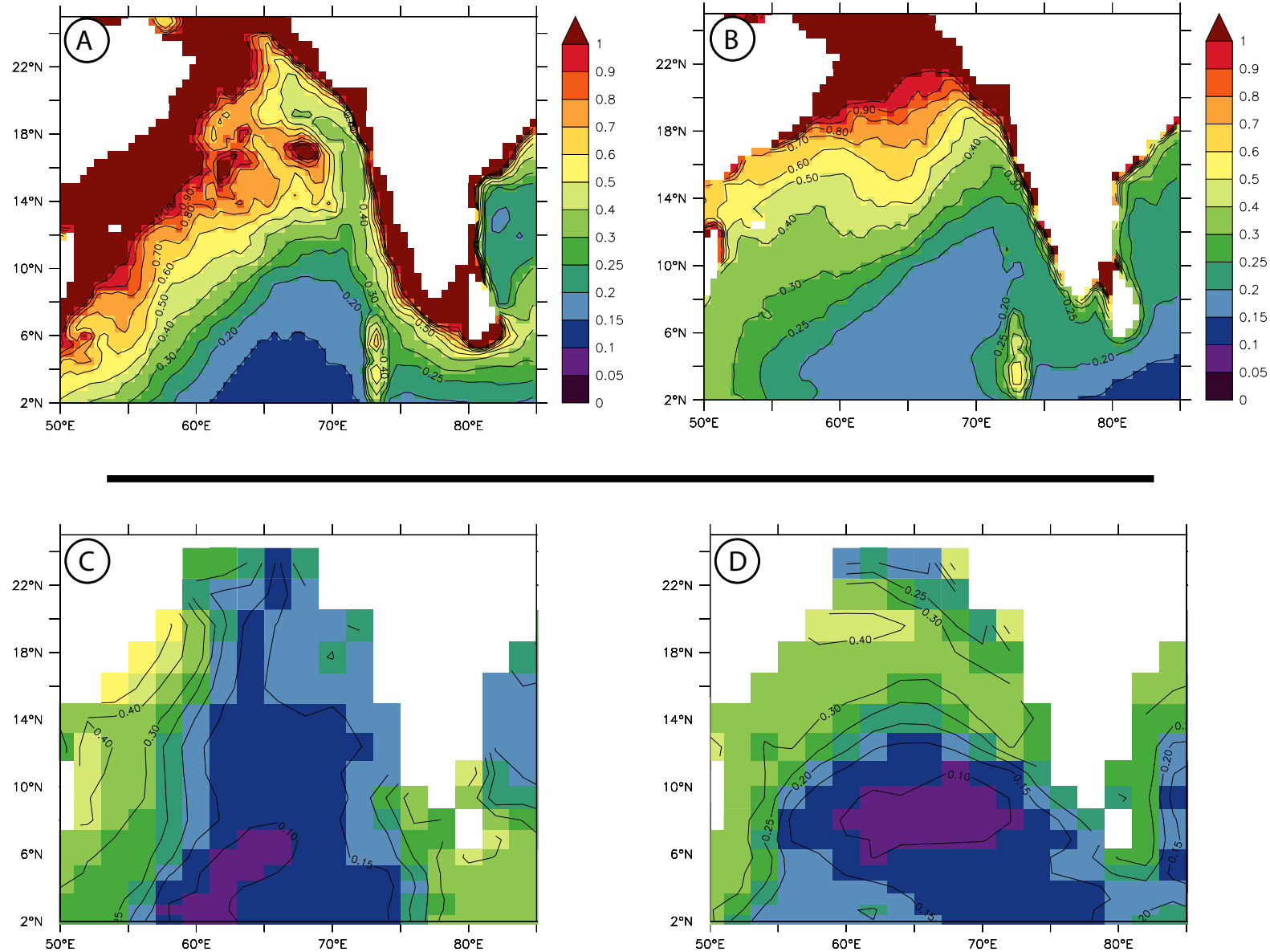

Fig. 2. Seasonal distribution of chlorophyll abundance $\left(\mathrm{mg} \mathrm{m}^{-3}\right)$ in the Tropical Indian Ocean (SeaWiFs data) during the summer (A) and winter (B) seasons. PISCES simulations of chlorophyll concentration $\left(\mathrm{mg} \mathrm{m}^{-3}\right)$ for the summer (C) and winter (D) seasons.

with the summer solstice. Within the Holocene, the SW monsoon reached a peak between $\sim 10$ and $8 \mathrm{ka}$ (Naidu and Malgrem, 1995, 1996; Gupta et al., 2003), in good accordance with independent paleo-monsoon records such as the speleothem oxygen series from the Qunf and Hoti caves, in Oman (Fleitmann et al., 2003). A recent synthesis of eighteen orbital-scale records ( $\sim 300 \mathrm{kyr}$ in length) even suggests that the phase lag relative to insolation may be large, with the strongest winds occurring $\sim 50^{\circ}$ after ice minima at the precession band and, therefore, $\sim 125^{\circ}$ after precession minima (Clemens et al., 2010). Such a phase relationship tends to suggest that, although northern summer insolation is a key element, it is not the only one that forces summer monsoon circulation intensity.

\subsubsection{G. bulloides abundance - productivity proxy}

In order to reconstruct past changes in wind-driven, upwelling intensity from our sediment records, we need first to choose a sensitive paleo-productivity index. Upwellig activity has a strong signature in the fluxes and composition of planktonic foraminifera assemblages (Cullen and Prell, 1984; Curry et al., 1992; Conan and Brummer, 2000). Within these assemblages, G. bulloides, which is a common midlatitude and subpolar species, is particularly abundant in eutrophic waters with high phytoplankton productivity (Sautter and Thunell, 1989; Ortiz et al., 1995; Watkins and Mix, 1998; Zaric et al., 2005), explaining its abundance in upwelling cells developing at various locations around the Arabian Sea, such as on the Oman Margin or on the western side of India (Prell and Curry, 1981; Naidu, 1990, 1993). In the northern Indian Ocean, G. bulloides relative abundance (Prell and Curry, 1981; Naidu and Malmgren, 1995; Gupta et al., 2003; Anderson et al., 2010) and G. bulloides flux (Conan and Brummer, 2000; Naidu and Malmgren, 1996) have been successfully used to reconstruct past changes in the intensity of monsoon-driven upwellings.

The planktonic foraminifera counts of core MD77-191 were obtained by Mléneck-Vautravers during her $\mathrm{PhD}$ thesis (Mléneck-Vautravers, 1997). Since the dry-bulk densities of core MD77-191 were not measured, G. bulloides fluxes could not be accurately computed at this site. Thus, in the 
Table 1. ${ }^{14}$ C-AMS dating of core MD77-191 (for Site ODP 723, see Gupta et al., 2003).

\begin{tabular}{llrrrrrrr}
\hline & & \multicolumn{2}{c}{${ }^{14} \mathrm{C}$ age } & & \multicolumn{3}{c}{ Calendar Age } \\
\cline { 3 - 4 } \cline { 7 - 8 } $\begin{array}{l}\text { Depth } \\
(\mathrm{m})\end{array}$ & Material & $\begin{array}{r}14 \mathrm{C} \text { age } \\
(\mathrm{yr})\end{array}$ & $\begin{array}{r}\text { Uncertainty } \\
(1 \sigma) \\
\end{array}$ & & & $\begin{array}{r}\text { Median } \\
\text { Probability } \\
(\mathrm{yr})\end{array}$ & $\begin{array}{r}\text { Lower } \\
\text { range } \\
(\mathrm{yr})\end{array}$ & $\begin{array}{r}\text { Upper } \\
\text { Range } \\
(\mathrm{yr})\end{array}$ \\
\hline 0.28 & G. bulloides & 1.970 & 60 & & 1.453 & 1.341 & 1.540 \\
0.76 & G. bulloides & 2.560 & 70 & & 2.148 & 2.042 & 2.286 \\
1.27 & G. bulloides & 3.020 & 60 & & 2.721 & 2.609 & 2.635 \\
1.75 & G. bulloides & 3.660 & 60 & & 3.492 & 3.377 & 3.590 \\
2.22 & G. bulloides & 4.160 & 60 & & 4.139 & 3.991 & 4.261 \\
2.71 & G. bulloides & 4.790 & 60 & & 4.980 & 4.831 & 5.078 \\
3.73 & G. bulloides & 6.150 & 80 & & 6.511 & 6.393 & 6.629 \\
4.25 & G. bulloides & 8.230 & 90 & & 8.676 & 8.517 & 8.843 \\
4.82 & G. bulloides & 8.970 & 80 & & 9.589 & 9.452 & 9.702 \\
5.94 & pteropods sp. & 12.630 & 190 & & 14270 & 13.764 & 14.676 \\
\hline
\end{tabular}

present paper, we will only consider the relative abundance of $G$. bulloides $(\%)$ as our paleo-productivity index. The high-resolution record of $G$. bulloides abundance in ODP Site 723 was published by Gupta et al. (2003). G. bulloides counts on both the MD77-191 core and at ODP Site 723 were obtained on the $>150 \mu \mathrm{m}$ fraction.

Gupta et al's \%G. bulloides record at ODP Site 723 shows lower percentages compared to similar records obtained in the same area (Anderson and Prell, 1993; Naidu and Malgrem, 1995, 1996). Anderson et al. (2010) suggested that this might be due to (1) differences in sample washing, which altered the preservation of $G$. bulloides, and/or (2) differences in taxonomic recognition (Gupta et al., 2003, being less inclusive in their classification of small, difficult to recognize juvenile forms). Within the present paper, Gupta et al.'s (2003) data were re-scaled following the procedure developed by Anderson et al., (2010) (rescaled $\%$ bulloides $=\%$ bulloides $\times 1.33+12$ ).

\subsubsection{Age model, ${ }^{14} \mathrm{C}$ dating}

On core MD77-191, the age model was developed based on nine accelerated mass spectrometry (AMS) ${ }^{14} \mathrm{C}$ dates obtained on monospecific $G$. bulloides samples, and a ${ }^{14} \mathrm{C}$ date obtained on pteropods (Mléneck Vautravers, 1997; Table 1). ODP Site 723 record spans the time interval $0.7-$ $10.7 \mathrm{ka}$ and is chronographically constrained by eleven ${ }^{14} \mathrm{C}$ dates obtained on $G$. bulloides or planktonic foraminifera mixes (Gupta et al., 2003). The ${ }^{14} \mathrm{C}$ ages were converted to calendar ages using the CALIB Rev 5.1 beta software (Stuiver and Braziunas, 1993), the marine calibration curve (Stuiver et al., 1998) and correcting for a surface marine reservoir of $\sim 400$ years for core MD777-191, and $\sim 600$ years for ODP Site 723 . In each core, the age model was developed by linear interpolation between ${ }^{14} \mathrm{C}$ dated control points (Fig. 3). The sedimentation rates at Site $723 \mathrm{~A}$ vary between 76 and $19 \mathrm{~cm} \mathrm{kyr}^{-1}$ (mean $\sim 34 \mathrm{~cm} \mathrm{kyr}^{-1}$ ) during the Holocene. MD77-191 shows sedimentation rates that vary between 91 and $23 \mathrm{~cm} \mathrm{kyr}^{-1}$ in the Holocene (mean sedimentation rate $\sim 61 \mathrm{~cm} \mathrm{kyr}^{-1}$ ). Owing to the high sedimentation rates at the two sites, bioturbation effects should not introduce significant biases on the paleoceanographic reconstructions (Duplessy et al., 1986; Bard, 2001).

\subsection{Model and experiments}

\subsubsection{Simulations with the IPSL climate model}

The IPSL-CM4 model couples (1) the grid point from the LMDZ atmospheric general circulation model (Hourdin et al., 2006) developed at the Laboratoire de Météorologie Dynamique (LMD, France) to (2) the oceanic general circulation model (Madec et al., 1998) developed at the Laboratoire d'Océanographie et du Climat (LOCEAN, ex LODYC, France). A sea-ice model (Fichefet and Morales Maqueda, 1997), which computes ice thermodynamics and dynamics, is included in the ocean model. On the continent, the land surface scheme ORCHIDEE (Krinner et al., 2005) is coupled to the atmospheric model. Only the thermodynamic component of ORCHIDEE is active in the simulations presented here. The closure of the water budget with the ocean is achieved thanks to a river routing scheme implemented in the land surface model. The ocean and atmospheric models exchange surface temperature, sea-ice cover, momentum, heat and fresh water fluxes, once a day, using the OASIS coupler (Terray et al., 1995) developed at CERFACS (France). None of these fluxes have been corrected.

The atmospheric grid is regular, with a resolution of $3.75^{\circ}$ in longitude, $2.5^{\circ}$ in latitude, and 19 vertical levels. The ocean model grid has approximately a $2^{\circ}$-resolution $\left(0.5^{\circ}\right.$ 

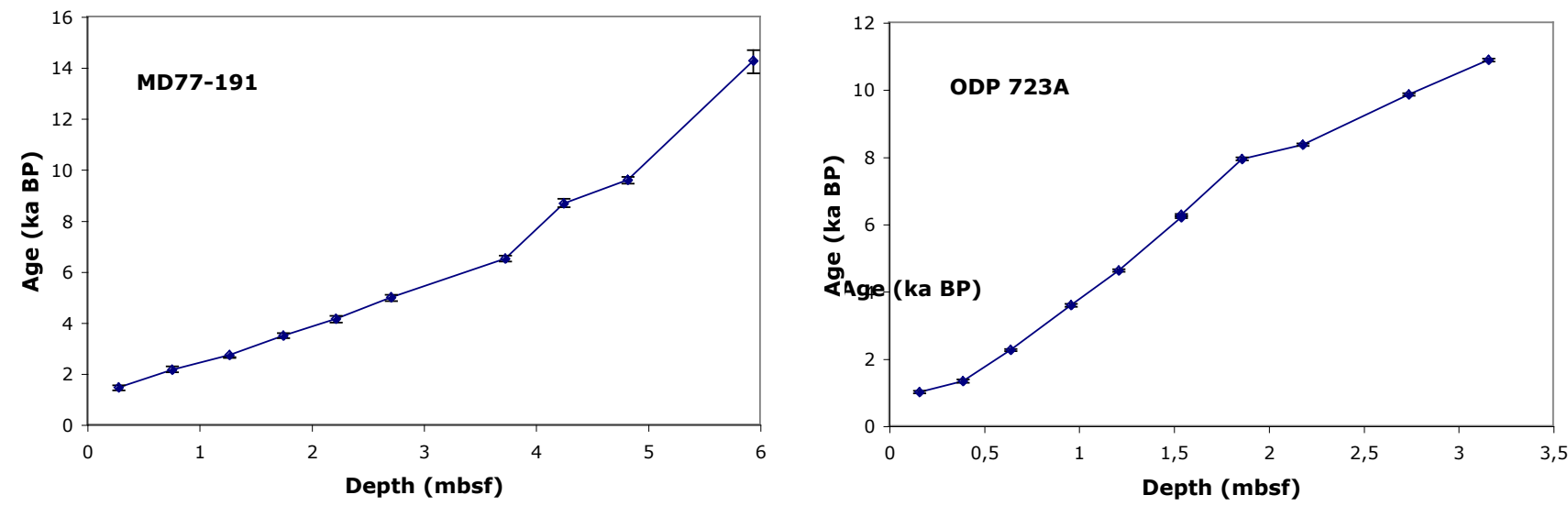

Fig. 3. Depth-age plots for core MD77-191 (left panel; see Table 2) and ODP site 723A (right panel; data from Gupta et al., 2003).

near the equator) with 182 points in longitude, 149 points in latitude and 31 levels in the ocean (Marti et al., 2010).

The reference (CTRL) is a $1000 \mathrm{yr}$ long simulation of the pre-industrial climate with trace gases concentration in the atmosphere prescribed to those of 1860; Marzin and Braconnot, 2009a). We consider, in the following, a mean seasonal cycle computed from $200 \mathrm{yr}$ of the simulation. Figure 1 shows that this simulation captures the large-scale features of the summer (Fig. 1c) and winter (Fig. 1d) monsoon flow (to be compared with meteorological data from Fig. 1a and b). Previous analyses (not shown) indicated that the characteristics of the pre-industrial simulation resemble those of modern simulations with the same version of the model, so that it makes sense to compare our pre-industrial runs with ERA interim reanalyses. In winter (DJFM) the surface flow pattern is properly reproduced. The $850 \mathrm{hPa}$ wind intensity is slightly overestimated along Somalia. The larger biases are found in summer (JJAS). These biases may affect part of the model-data comparison and, therefore, need to be considered. In particular, the monsoon flow does not penetrate far enough into the Arabian Sea. Thus, wind directions and intensity are not well reproduced along the western Indian coast. The wind intensity along Somalia and the Oman margin is also underestimated, which affects the northward extent and the strength of the simulated upwelling.

Simulations of the Indian monsoon at $9 \mathrm{ka}$ (early Holocene) and $6 \mathrm{ka}$ (mid-Holocene) are described in Marzin and Braconnot (2009a). In these simulations the date of the vernal equinox is fixed to March 21 at noon, following PMIPII protocol (Braconnot et al., 2007a). Trace gases are prescribed to the pre-industrial values, so that only the changes in the orbital parameters are accounted for. They have been computed following Berger (1978). The initial state for the atmosphere corresponds to a 1 January representative of present day climate. The model was integrated from an ocean at rest with temperature and salinity prescribed to the Levitus's (1982) climatology. The model is then run long enough (300 years for early Holocene to 700 years for
mid-Holocene), so that the surface and middle ocean are equilibrated with the forcing. Previous results with these simulations described the evolution of Indian precipitation (Marzin and Braconnot, 2009a), the impact of the SST response on Indian and east-Asian precipitations (Marzin and Braconnot, 2009b) and the surface stratification of the Indian Ocean between the tip of India and the equator (Braconnot et al., 2008).

\subsubsection{Biogeochemical model: PISCES}

PISCES (Pelagic Interaction Scheme for Carbon and Ecosystem Studies) simulates the cycling of carbon, oxygen, and of the major nutrients determining phytoplankton growth $\left(\mathrm{PO}_{4}^{3-}, \mathrm{NO}_{3}^{-}, \mathrm{NH}_{4}^{+}, \mathrm{Si}, \mathrm{Fe}\right)$. Phytoplankton growth is limited by the availability of nutrients, temperature, and light. The model has two phytoplankton size classes (small and large), representing nanophytoplankton and diatoms, as well as two zooplankton size classes (small and large), representing microzooplankton and mesozooplankton. For all species the $\mathrm{C}: \mathrm{N}: \mathrm{P}$ ratios are assumed constant (122:16:1), while the internal ratios of $\mathrm{Fe}: \mathrm{C}, \mathrm{Chl}: \mathrm{C}$, and $\mathrm{Si}: \mathrm{C}$ of phytoplankton are predicted by the model. There are three non-living components of organic carbon in the model: semi-labile dissolved organic carbon (DOC), with a lifetime of several weeks to years, as well as large and small detrital particles, which are fuelled by mortality, aggregation, faecal pellet production and grazing. Small detrital particles sink through the water column with a constant sinking speed of $3 \mathrm{~m} \mathrm{day}^{-1}$, while for large particles the sinking speed increases with depth from a value of $50 \mathrm{~m} \mathrm{day}^{-1}$ at the depth of the mixed layer, increasing to a maximum sinking speed of $425 \mathrm{~m} \mathrm{day}^{-1}$ at $5000 \mathrm{~m}$ depth. These rates are consistent with those measured by Honjo (1996) and Clemens (1998) in Arabian Sea sediment traps. For a more detailed description of the PISCES model, see Aumont and Bopp (2006) and Gehlen et al. (2007).

PISCES was run in its offline configuration, i.e. monthly output of the climate simulations (currents, temperature, 
salinity, winds, radiations, ...) were used to compute biological processes, as well as advection /diffusion of the passive tracers within PISCES. Accordingly, PISCES simulations are run on a global grid, with 31 levels on the vertical (10 of which are located in the first $100 \mathrm{~m}$ ) and $2^{\circ} \times 2^{\circ}$ cos lat for the horizontal resolution. For this work, two biogeochemical simulations were carried out for $500 \mathrm{yr}$, using climatologies constructed from IPSL-CM4 runs for $6 \mathrm{ka}$ and Preindustrial. The analysis was done on the last year of each of the simulation.

The modelled surface chlorophyll concentrations for preindustrial times (Fig. 2c and d) are compared to the SeaWiFS climatology data of Levy et al. (2007), for Summer (JJAS) and Winter (DJFM) seasons (Fig. 2a and b). The general pattern that consists of two phytoplankton blooms (summer and winter blooms) driven by the summer southwest monsoon and the winter northeast monsoon respectively is reproduced by the biogeochemical model. The magnitude of these blooms is, however, underestimated. During the summer season in the upwelling area over the Oman Margin, for instance, the Seawifs data indicate that chlorophyll abundance is $>1 \mathrm{mg} \mathrm{m}^{-3}$ (Fig. 2a), whereas estimated chlorophyll abundance remains around $0.3-0.4 \mathrm{mg} \mathrm{m}^{-3}$ in the PISCES simulation (Fig. 2c). The main reason for this discrepancy is linked to the coarse resolution of both the atmosphere (LMDZ) and ocean (OPA) general circulation models that force the biogeochemical model, and that precludes a good representation of coastal upwelling zones. Indeed, a similar version of the PISCES model, coupled to OPA at $0.5^{\circ}$ resolution and forced by reanalysis products has been compared to the same data set over the 1990-1999 period and it reproduced nicely the distribution, the seasonality and the magnitude of surface chlorophyll changes (Koné et al., 2009).

\subsubsection{The FORAMCLIM ecophysiological model}

The FORAMCLIM model (Lombard et al., 2011) is an eco-physiological model reproducing the growth of eight foraminifera species (including $G$. bulloides). It is based on the assumption that a species occurrence in an ecosystem is linked to its ability to grow, depending on the environmental conditions. The model reproduces the physiological rates involved in the growth of planktonic foraminifers and is principally based on biological processes (e.g. respiration, symbiont photosynthesis, nutrition, growth) observed under controlled laboratory experiments. The calibration of the model has been presented in Lombard et al. (2011) and uses both observed growth under laboratory conditions in function of temperature and light intensity, and observed abundance in field conditions for which hydrological characteristics have been measured. FORACLIM model needs temperature, food (Chl- $a$ ) and light as inputs and estimate as outputs the growth rates of the eight species that are converted to potential abundances in the water column.
Table 2. Comparison of modelled and observed G. bulloides abundance $(\%)$ in foraminifer assemblages at the locations of ODP Site 723 and core MD77-191, at $6 \mathrm{ka} \mathrm{BP}$ and for the modern control run (considered equivalent to uppermost Holocene observations). The observed $G$. bulloides abundances at core MD77-191 and ODP Site 723 are mean values (5-point window) derived from the bulk data obtained by Mléneck-Vautravers (1997) and Gupta et al. (2003; rescaled based on Anderson et al., 2010), respectively.

\begin{tabular}{lcclcc}
\hline & \multicolumn{2}{c}{$\begin{array}{c}\text { Oman Margin } \\
\text { (ODP Site 723) }\end{array}$} & & \multicolumn{2}{c}{$\begin{array}{c}\text { South of India } \\
\text { (MD77-191) }\end{array}$} \\
\cline { 2 - 3 } \cline { 5 - 6 } \cline { 5 - 6 } & Modeled & Observed & & Modeled & Observed \\
\hline $\begin{array}{l}\text { Pre-industrial } \\
\text { control run }\end{array}$ & $17.3 \%$ & $26.4 \%$ & & $19.3 \%$ & $45.3 \%$ \\
$\begin{array}{l}\text { Mid-Holocene } \\
(6 \mathrm{ka})\end{array}$ & $19.8 \%$ & $32.3 \%$ & & $16.3 \%$ & $34.1 \%$ \\
\hline
\end{tabular}

At the two sites of interest, we forced the FORACLIM model with monthly mean outputs from the IPSL-CM4 (temperature, light) and PISCES (food) simulations performed under pre-industrial (CTRL) and Mid-Holocene (6 ka) conditions. Abundance estimates of each species were cumulated over months and depths in order to derive a signal, which could be compared to the actual sedimentary records (Table 2). As can be seen from the comparison of the controlrun simulation and the core top data, the modelled G. bulloides proportion (17.3\% for the Oman Margin, and $19.3 \%$ for the southern tip of India) are clearly underestimated, corresponding to about half of the observed G. bulloides proportion in the sediment (26.4\% at ODP Site 723, Oman Margin and $45.3 \%$ in core MD77-191, south of India). These low, modelled G. bulloides abundances likely reflect the underestimation of marine productivity and biomass by PISCES as discussed above.

\section{Link between past productivity and the Indian monsoon evolution}

\subsection{Upwelling and wind evolution revealed by Site 723 and core MD 77-191 proxy records}

Both the ODP Site 723A and MD77-191 records were resampled at the same, constant time-interval of $0.3 \mathrm{kyr}$. Then, in order to extract long-term evolution over the Holocene, a 5-point window moving average was applied to both records. Raw and smoothed data from ODP Site 723 and core MD77191 are presented in Fig. 4a and b, respectively. The low latitude $\left(30^{\circ} \mathrm{N}\right)$ summer insolation has been calculated for the last $12 \mathrm{kyr}$ using the Analyserie Software (Paillard et al., 1996) and is displayed in Fig. 4c for comparison. It should be noted that, since the main topic of this paper it the comparison of the long-term (Holocene) evolution of the 

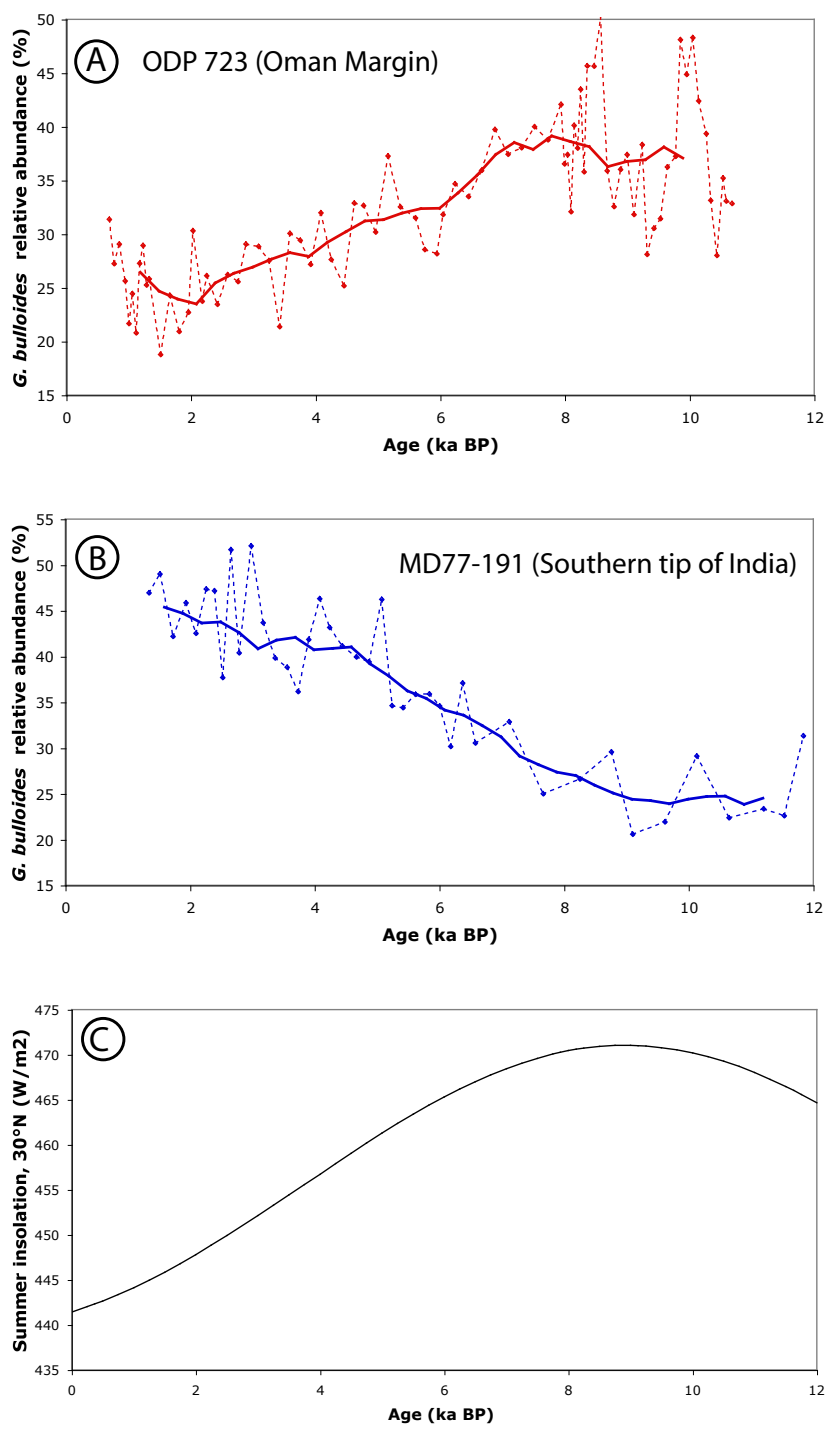

Fig. 4. (A) G. bulloides percentages versus age in ODP Site 723 (Oman Margin; Gupta et al., 2003). (B) G. bulloides percentages versus age in core MD77-191 (southern tip of India; MladeckVautravers, 1997). (C) Boreal summer insolation at $30^{\circ} \mathrm{N}$ over the last $12 \mathrm{kyr}$. Dashed-line curves represent $\%$ G. bulloides data re-sampled at a constant, $0.3 \mathrm{kyr}$ interval. The thick-line curves represent smoothed records (5-point moving average).

two upwelling areas, no special attention has been devoted to carefully constrain the phase relationship (lead/lag) between maxima (minima) in upwelling intensity and maxima (minima) of insolation forcing. Thus, the summer insolation at $30^{\circ} \mathrm{N}$ is just a convenient curve used to illustrate the longterm evolution of orbital function, and we draw no conclusion from the relative phasing between this curve and the upwelling intensity variations.

\subsubsection{Oman margin (site ODP 723A)}

The smoothed, temporal evolution of G. bulloides abundance shows that, on a long-term basis (orbital scale) the Oman margin productivity was at its maximum near the beginning of the Holocene ( $\sim 9 \mathrm{ka})$. Then, over the course of the Holocene, a clear tendency of decreasing G. bulloides abundance is observed, with the lowest inferred activity between about 2 and $1.5 \mathrm{kaBP}$. The subsequent increase in productivity since $\sim 1.5 \mathrm{ka} \mathrm{BP}$ has been attributed to (1) change in the date of aphelion, and/or (2) the effects of agricultural and other human land uses on the monsoon (Anderson et al., 2010).

The reduction of summer monsoon upwelling activity along the course of the Holocene deduced from the G. bulloides record is coherent with the $\delta^{15} \mathrm{~N}$ record of core NIOP 905, collected off the coast of Somalia from a water depth of $\sim 1580 \mathrm{~m}$ (Ivanochko et al., 2005). This long-term reduction in ODP Site 723 upwelling intensity appears to follow the progressive decrease of the Northern Hemisphere summer insolation, which results from the Holocene evolution of the Earth's orbital parameters (Fig. 4c).

\subsubsection{Southern tip of India (core MD77-191)}

Opposite to what we have just observed for the Oman Margin site, the G. bulloides relative abundance at the southern tip of India reaches its lowest level at the beginning of the Holocene ( $\sim 9 \mathrm{ka}$ BP; Fig. $4 \mathrm{~b})$. This suggests that productivity was lower than today when low latitude boreal summer insolation was at its maximum (Fig. $4 \mathrm{c}$ ). From $\sim 9 \mathrm{kaBP}$ to the present, the $G$. bulloides relative abundance increases continuously in core MD77-191, suggesting that productivity has gradually increased throughout the Holocene. The maximum in G. bulloides abundance is reached at the top part of the record, at around $2.1 \mathrm{kaBP}$.

\subsubsection{Implication of the two G. bulloides records}

Today, the annual productivity at the location of ODP Site 723 and core MD77-191 is chiefly controlled by the development of summer monsoon upwellings. But what about the long-term (Holocene) evolution indicated by the sedimentary records? The opposite evolution shown by ODP Site 723 and MD77-191 G. bulloides records could either suggest that (1) the productivity at one of these sites did not remain chiefly associated to summer monsoon upwelling activity along the course of the Holocene, or, alternatively, (2) that the productivity did remain chiefly upwellingcontrolled at these two sites and, therefore, summer wind intensity showed an opposite evolution on the Oman margin and at the Southern tip of India in response to change in insolation forcing. In order to help interpret our paleoproductivity records and to test which of these assumptions is correct, we used model simulations to look at the relationship 
$6 \mathrm{ka}-\mathrm{CTRL}$

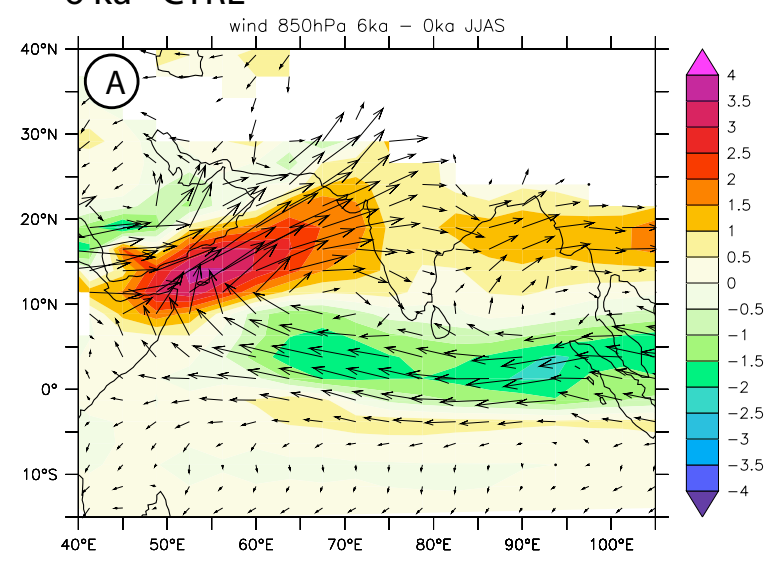

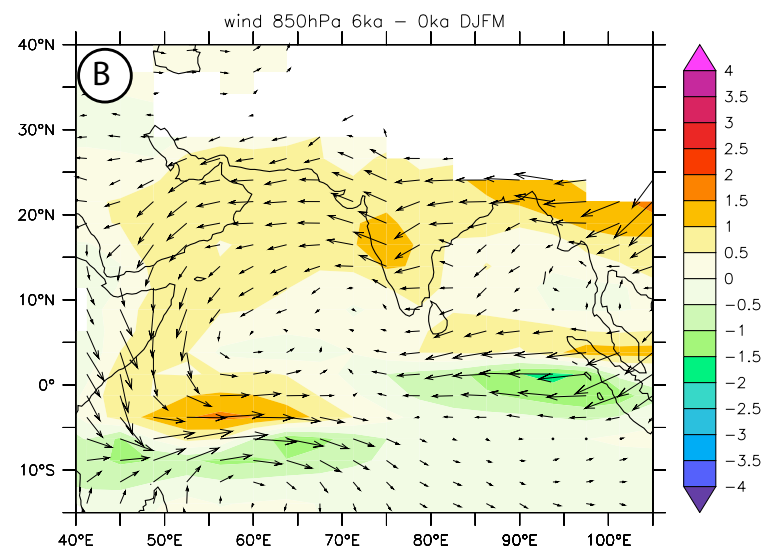

9 ka - CTRL

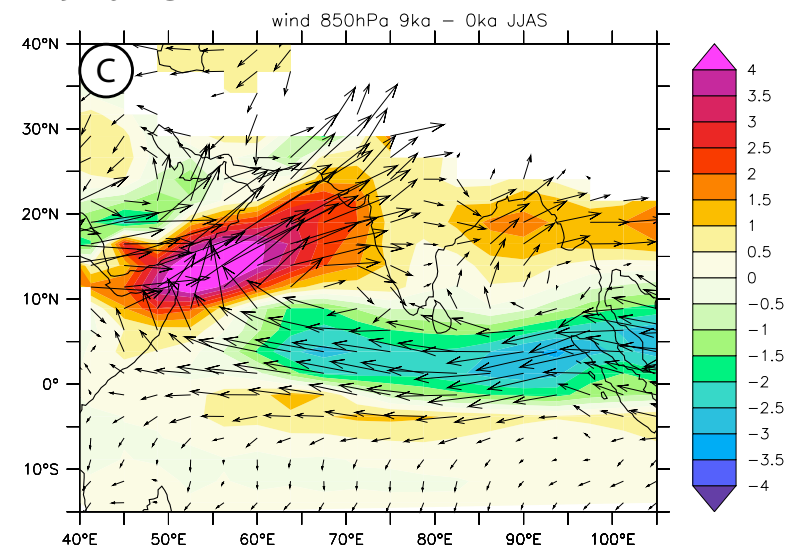

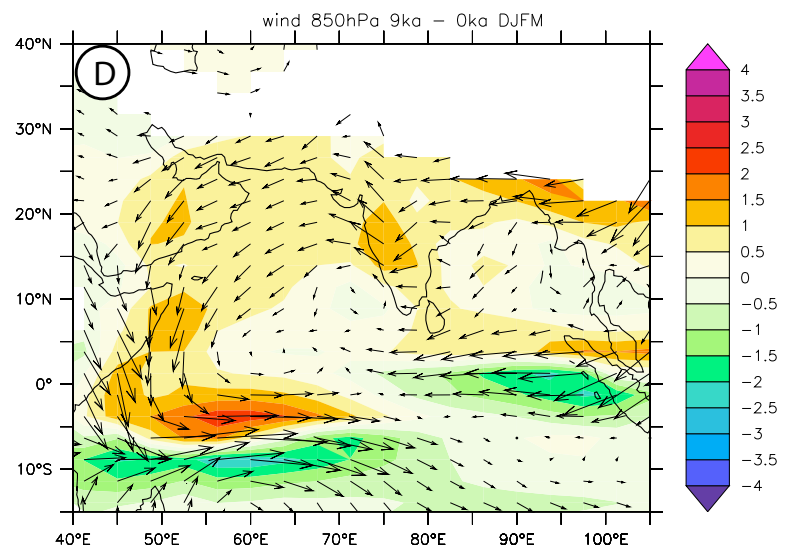

Fig. 5. Early and mid-Holocene wind simulations from the IPSL-CM4 model at the $850 \mathrm{hPa}$ level. In all figures we plotted the differences with the pre-industrial run (control run) for the wind directions (vectors) and intensity (color scale, in $\mathrm{m} \mathrm{s}^{-1}$ ). (A) Summer simulation, $6 \mathrm{ka} \mathrm{BP}$. (B) Winter simulation, 6 ka BP. (C) Summer simulation, 9 ka BP. (D) Winter simulation, $9 \mathrm{ka} \mathrm{BP.}$

between wind forcing and marine productivity across the Holocene.

\subsection{Link between productivity and larger-scale summer monsoon wind}

We first consider the $6 \mathrm{ka}$ time-slice for which the simulations performed with the IPSL-CM4 and PISCES models make it possible to analyze the consistency between the changes in the monsoon flow, wind and ocean productivity.

In response to the strengthening of seasonality in the Northern Hemisphere, both the winter and the summer monsoons were enhanced during the mid-Holocene compared to the present (Fig. 5a and b). As a result, northeasterly winds were stronger along the Oman margin during boreal winter and southwesterly winds were stronger during summer. The larger changes were found in summer when wind speed differences with the pre-industrial simulation exceeded $3 \mathrm{~m} \mathrm{~s}^{-1}$ at the coast (Fig. 5a). The monsoon flow intensification is associated to an anomalous anticlockwise wind pattern resulting in an intensification of the wind in winter at the tip of India and to a clockwise pattern in summer leading to a reduction of the wind. Even though the changes occurring during the summer season are the largest, it is important to check which season is dominant in the change of ocean export production and $G$. bulloides abundance in the marine sediments.

Figure 6 shows a map of the differences in particulate export production at $100 \mathrm{~m}$ (Fig. 6a) between $6 \mathrm{ka}$ and $0 \mathrm{ka}$ in the Arabian Sea, as well as a comparison of $6 \mathrm{ka}$ and pre-industrial reconstructions of annual (monthly) evolution of export production obtained by PISCES at site ODP 723 (Fig. 6b) and core MD77-191 (Fig. 6c) locations. These results indicate that using the bio-geochemical PISCES model and the ocean physics simulated by the IPSL-CM4 model at $6 \mathrm{ka} \mathrm{BP}$ and for the pre-industrial, we qualitatively reproduce the variations reconstructed from the $G$. bulloides productivity proxy at the ODP 723 and MD77-191 sites, that 

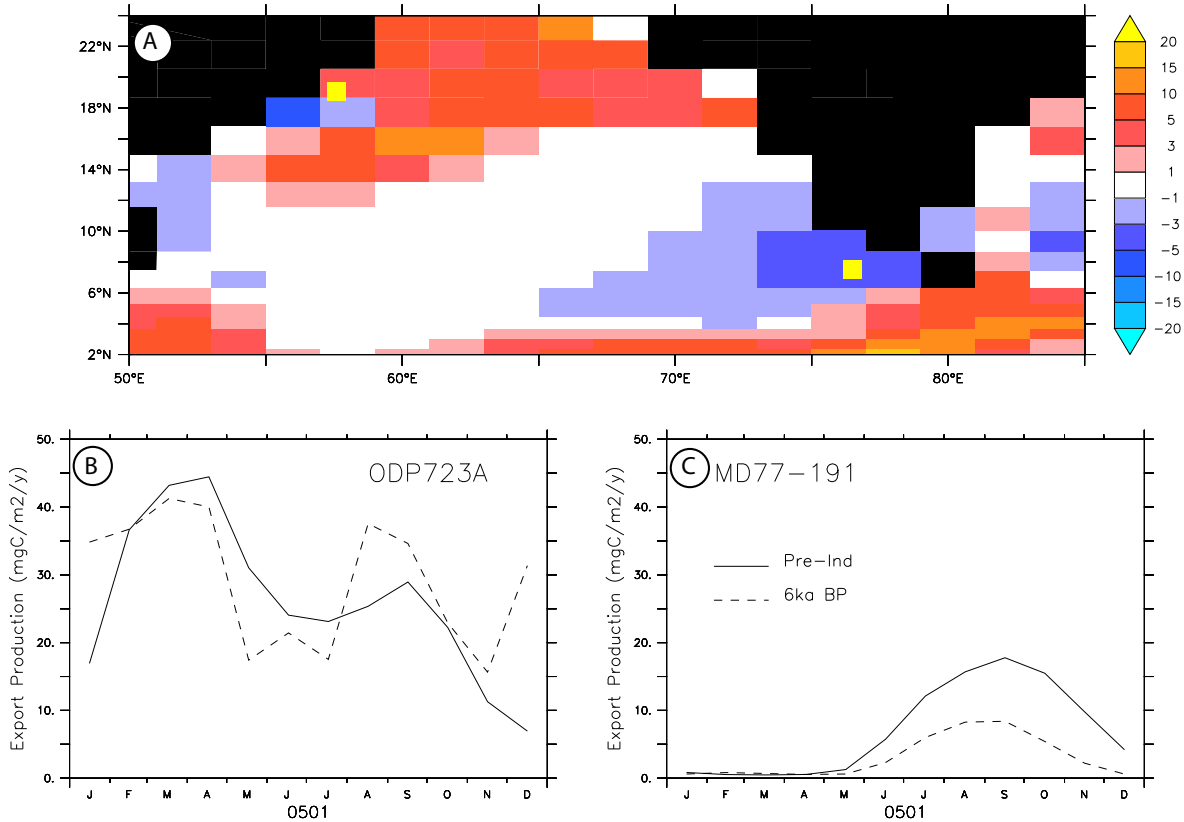

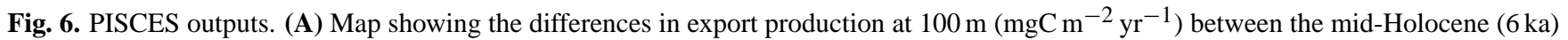
and the pre-industrial control-run simulations. (B) Seasonal variations of export production simulated at $6 \mathrm{ka} \mathrm{BP}$ and in the control run, at the ODP Site 723. (C) Seasonal variations of export production simulated at $6 \mathrm{ka} \mathrm{BP}$ and in the control run, at the site of core MD77-191. Yellow squares indicate the location of ODP Site 723 and core MD77-191 in panel (A).

is: more export production at $6 \mathrm{kaBP}$ on the Arabian coast, and less export at the Southern tip of India compared to the pre-industrial simulation. South of India, this difference (less export at $6 \mathrm{ka}$ ) seems directly related to the characteristics of the summer bloom, and thus to the intensity of the monsoon upwelling. In the western Arabian Sea, even if the simulated changes agree in average (see map on Fig. 6a), the message is complicated by the seasonality of the bloom. This region is characterized by two blooms: a summer bloom related to the monsoon and upwelling, and a winter bloom linked to the deepening of the mixed layer (see Levy et al., 2007). The characteristics of these two blooms are modified during the Holocene, as opposed to the Pre-Industrial. The summer bloom is driven by the characteristics of the monsoon upwelling: its intensity increases significantly. The winter bloom is also largely impacted: its timing is modified and an earlier start also contributes to the difference in the average annual export.

Mean outputs from IPSL-CM4 (temperature, light) and PISCES (food) simulations were used to emulate the FORAMCLIM ecophysiological model (6 ka and preindustrial, control-run). As already mentioned above, the resulting G. bulloides proportion in the pre-industrial run is around half of the observed one in recent sediments, which is not surprising considering the coarse resolution of both the atmosphere (LMDZ) and the ocean (OPA) general circulation models that force PISCES, the biogeochemical model, precluding a good representation of coastal upwelling zones.
Yet, the evolution of the G. bulloides proportion are reproduced in a correct way by the FORAMCLIM model (Table 2), with an increase of G. bulloides at the southern tip of India between $6 \mathrm{ka}(16.3 \%)$ and pre-industrial conditions $(19.3 \%$ ) (compared to the observed increase between $~ 35 \%$ and $\sim 45 \%$ ), whereas the simulated proportion decrease in the Oman margin from 19.8 to $17.3 \%$ (compared to the observed decrease from $\sim 32 \%$ to $\sim 25 \%$ ).

\subsection{Differences between the early and the mid Holocene}

As seen above, the complete set of model simulations obtained at $6 \mathrm{ka}$ (IPSL-CM4, PISCES and FORAMCLIM) are consistent with G. bulloides records from ODP Site 723 and MD77-191. These simulations (1) confirm that productivity at these two sites has always been chiefly associated to monsoon-driven, summer upwelling activity, and (2) they reproduce the opposite, long-term evolution of productivity recorded in the $G$. bulloides records at the two sites (i.e. more export production at $6 \mathrm{ka} \mathrm{BP}$ on the Arabian coast, and less export at the Southern tip of India compared to the preindustrial simulation).

For this paper, no PISCES simulation was available at $9 \mathrm{ka}$, but simulations of surface winds obtained with the IPSL-CM 4 model were available at $9 \mathrm{ka}, 6 \mathrm{ka}$ and could be compared to the pre-industrial control run (Fig. 5). These 9 and $6 \mathrm{ka}$ simulations show that the inverse evolution of the Oman margin and southern India productivity recorded in the 
$\%$ G. bulloides data from sites ODP 723 and MD77-191 is fully consistent with the modelled, local evolution of summer wind forcing at these two locations. Over the Oman margin, summer monsoon winds were clearly enhanced at $9 \mathrm{ka}$ compared to the pre-industrial reference (6 ka showing intermediate values; Fig. 5a and c). Over the southern tip of India the wind evolution is opposite. The western winds that prevail during the summer monsoon were lowest at $9 \mathrm{ka}$ compared to today. As already discussed by Marzin and Braconnot (2009a), this is related to the fact that the entire dynamic structure of the Indian monsoon flow is shifted northward and penetrates further inland at $9 \mathrm{ka} \mathrm{BP}$ in the IPSL-CM4 reconstruction. These authors concluded that the monsoon system is amplified over India in response to a large meridional temperature gradient and an intensified contrast in land-sea temperature, these changes being ultimately forced by the insolation changes. The northernmost position reached by the monsoon rain belt at the peak boreal summer insolation, $9 \mathrm{kyr}$ ago, is independently supported by the $\delta^{18} \mathrm{O}$ record of the Qunf Cave's speleothem (southern Oman; Fleitmann et al., 2003). On this record, the $\delta^{18} \mathrm{O}$ values become gradually lighter over the past $10 \mathrm{kyr}$, a trend that has been interpreted as resulting from the progressive southward migration of the ITCZ as boreal summer insolation reduces over the course of the Holocene.

Figure 7 compares the evolution of $\%$ G. bulloides records from cores ODP 723 and MD77-191 with the upwelling velocities modeled at these sites at $9 \mathrm{ka}, 6 \mathrm{ka}$ and $0 \mathrm{ka}$. Twenty decades of vertical velocities are individually plotted to show the decadal variability of the upwelling for each period. In the Oman Sea (core ODP 723), the changes of the upwelling velocities from $9 \mathrm{ka}$ to $0 \mathrm{ka}$ are significant, with a smaller change between $9 \mathrm{ka}$ and $6 \mathrm{ka}$ than between $6 \mathrm{ka}$ and $0 \mathrm{ka}$. The decrease of the biological activity depicted by G. bulloides relative abundance is fully coherent with the reduction of the upwelling estimated by the IPSL-CM4 model throughout the Holocene. At the southern tip of India (core MD7791), the upwelling change between $6 \mathrm{ka}$ and $0 \mathrm{ka}$ is significant. The change between $9 \mathrm{ka}$ and $6 \mathrm{ka}$ is slightly smaller, with a large decadal variability, which reduces the significance. At this location also, the \% G. bulloides sedimentary record and the modeled upwelling intensity are coherent, with a decrease of the upwelling associated to a decrease of the biological activity along the course of the Holocene.

Thus, for both cores, model and data fit well, which supports the interpretation of $G$. bulloides' relative abundance as a proxy of the upwelling intensity and, therefore, wind forcing. Model and data are coherent and indicate a reduction of wind intensity since $9 \mathrm{ka}$ over the Oman margin, associated to the decrease of boreal summer insolation. At the Southern tip of India, summer winds increase since $9 \mathrm{ka}$ due to the progressive shift to the south of the regional circulation pattern.
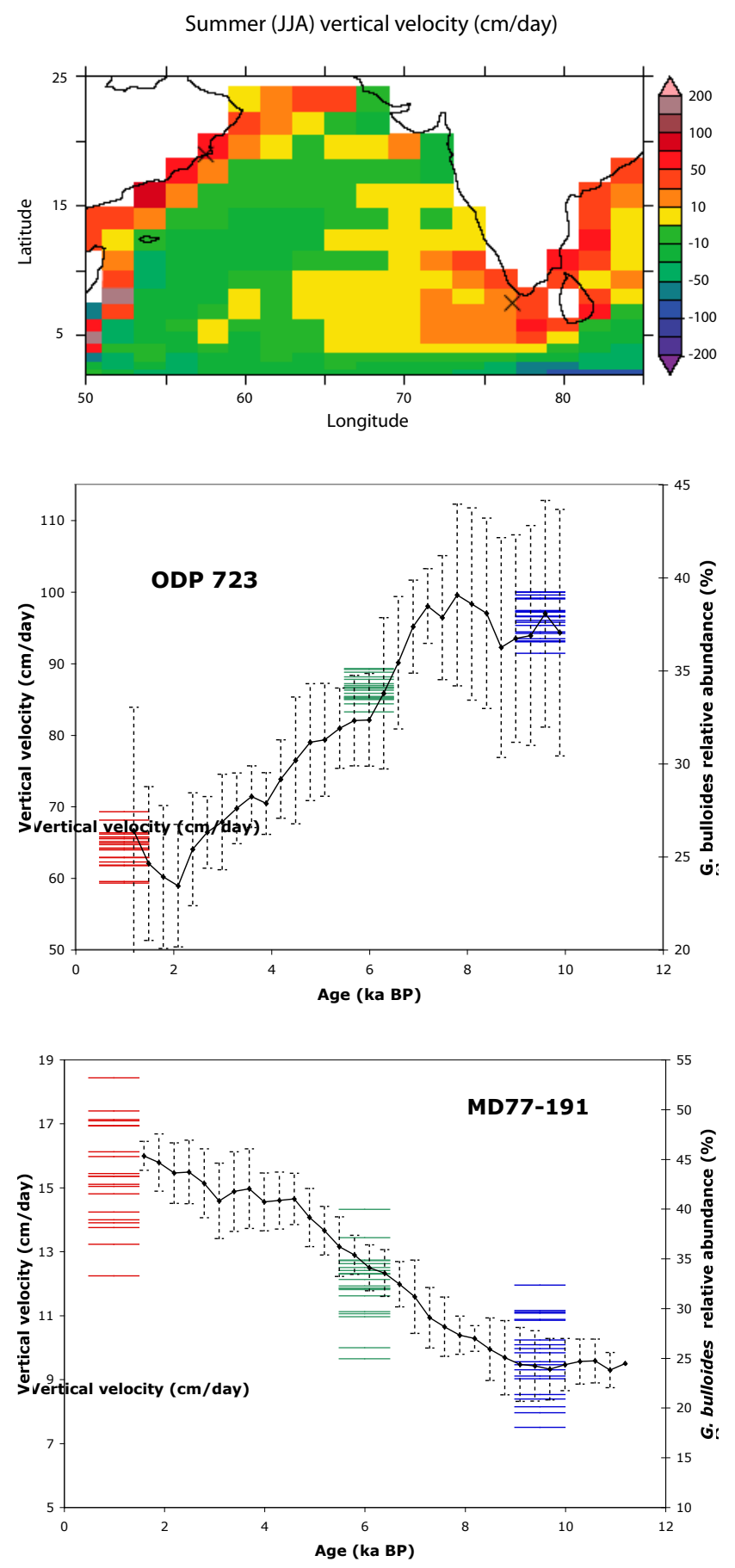

Fig. 7. (A) Map of summer vertical velocity $\left(\mathrm{cm} \mathrm{day}^{-1}\right)$ reconstructed with the IPSL-CM4 model in the control-run simulation. Data/model comparison of upwelling intensity evolution across the Holocene at the locations of Site ODP 723 (B) and core MD77191 (C). G. bulloides data have been re-scaled ( $0.3 \mathrm{kyr}$ interpolation) and smoothed (5-point moving average). Uncertainties are standard deviations estimated over the 5-point windows. Model outputs are mean, vertical velocities estimated at grid-points near the locations of core MD77-191 and ODP Site 723. Black crosses indicate the location of ODP Site 723 and core MD77-191 in the map of panel (A). 


\section{Conclusions}

Two summer monsoon upwellings, one over the Oman Margin and the other south of India, show opposite long-term evolution over the Holocene. While the former shows a coherent response to boreal summer insolation and decreases in intensity since $\sim 9 \mathrm{ka}$, the latter shows an opposite response and increases in intensity towards the recent.

Paleo-reconstructions of wind patterns, marine productivity and foraminifera assemblages were obtained using the IPSL-CM4 climate model coupled to the PISCES marine biogeochemical model and the FORAMCLIM ecophysiological model. These reconstructions are fully coherent with the marine core data. They confirm that the evolution of particulate export production and foraminifera assemblages at our two sites have been directly linked with the strength of the upwelling. The opposite, long-term evolution observed from G. bulloides (productivity) records at the Oman and South Indian sites is correctly reproduced through modelisation. IPSL-CM4 model runs at 9 and 6 ka show that, while the Oman Margin summer wind intensity follows the change in summer insolation, the increase in wind intensity since $9 \mathrm{ka}$ at the southern tip of India results from the southward shift of monsoon winds over the Arabian Sea.

The simulated changes are, however, smaller than observed, due (1) to the low resolution of the climate model that does not allow proper representation of the strength of the regional upwellings and (2) to the systematic underestimation of the northward extent of the boreal summer monsoon flow in the northern Arabian Sea in the control simulation. The good agreement on the relative evolution of the two upwellings during the Holocene also provides the important confirmation that the changes recorded in the ocean sediments are dominated by large-scale changes in the atmosphere and ocean circulation and not by local processes at the scale of the upwellings. Our results also show that the combination of climate simulations with simulations of the ocean biochemistry coupled to a foraminifer, ecophysiological model offers new perspectives in model data comparisons and in the understanding of past changes. They help to refine the criteria to test the response of climate models to the insolation forcing and show how the confrontation of model results with proxy records help us to better understand the spatio-temporal evolution of Indian monsoon flow across the Holocene.

Acknowledgements. The authors thank E. Michel, B. Malaizé and L. Labeyrie for fruitful discussions during the development of this research project, and S. Clemens and D. Anderson for their very helpful reviews. This work was supported by CEA through a CFR grant. This is Past4Future contribution no 9. The research leading to these results has received funding from the European Union's Seventh Framework programme (FP7/2007-2013) under grant agreement no 243908, " Past4Future. Climate change - Learning from the past climate". This work has been also supported through the French ANR projects FORCLIM (05-BLANC-275-01), ELPASO (10-BLANC-608-01), and ECOLOGY (10-PDOC-005-01). This is LSCE contribution 4611.

Edited by: N. Abram

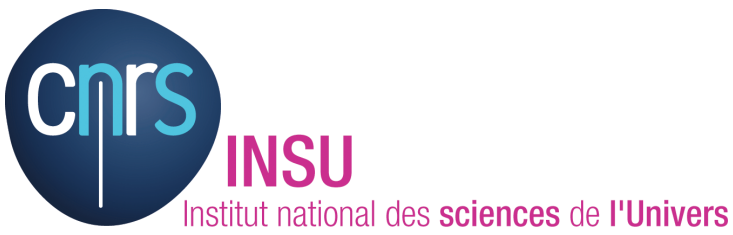

The publication of this article is financed by CNRS-INSU.

\section{References}

An, Z., Porter, S .C., Kutzbach, J. E., Wu, X., Wang, S., Liu, X., Li, X., and Zhou W.: Asynchronous Holocene optimum of the East Asian monsoon, Quaternary Sci. Rev., 19(8), 743-762, 2000.

Anderson, D. and Prell, W.: A 300 kyr record of upwelling off oman during the late quaternary: Evidence of the Asian Southwest monsoon, Paleoceanography, 8(2), 193-208, 1993.

Anderson, D. M., Baulcomb, C. K., Duvivier, A. K., and Gupta, A. K.: Indian summer monsoon during the last two millennia, J. Quaternary Sci., 25(6), 911-917, doi:10.1002/jqs.1369, 2010.

Ashok, K., Guan, Z. , Saji, N. H.,and Yamagata, T.: Individual and Combined Influences of ENSO and the Indian Ocean Dipole on the Indian Summer Monsoon, J. Climate, 17, 3141-3155, 2004.

Aumont, O. and Bopp, L.: Globalizing results from ocean in situ iron fertilization studies, Global Biogeochem. Cy., 20, GB2017, doi:10.1029/2005GB002591, 2006.

Bard, E.: Paleoceanographic implications of the difference in deepsea sediment mixing between large and fine particles, Paleoceanography, 16(3), 235-239, 2001.

Berger, A. L.: Long-term variations of daily insolation and Quaternary climatic changes, J. Atmos. Sci., 35(12), 2362-2367, 1978.

Braconnot, P. and Marti, 0.: Impact of précession on monsoon characteristics from coupled ocan atmosphère experiments: changes in Indian monsoon and Indian ocean climatology, Mar. Geol., 201, 23-34, 2003.

Braconnot, P., Otto-Bliesner, B., Harrison, S., Joussaume, S., Peterchmitt, J.-Y., Abe-Ouchi, A., Crucifix, M., Driesschaert, E., Fichefet, Th., Hewitt, C. D., Kageyama, M., Kitoh, A., Laîné, A., Loutre, M.-F., Marti, O., Merkel, U., Ramstein, G., Valdes, P., Weber, S. L., Yu, Y., and Zhao, Y.: Results of PMIP2 coupled simulations of the Mid-Holocene and Last Glacial Maximum Part 1: experiments and large-scale features, Clim. Past, 3, 261277, doi:10.5194/cp-3-261-2007, 2007a.

Braconnot, P., Otto-Bliesner, B., Harrison, S., Joussaume, S., Peterchmitt, J.-Y., Abe-Ouchi, A., Crucifix, M., Driesschaert, E., Fichefet, Th., Hewitt, C. D., Kageyama, M., Kitoh, A., Loutre, M.-F., Marti, O., Merkel, U., Ramstein, G., Valdes, P., Weber, L., Yu, Y., and Zhao, Y.: Results of PMIP2 coupled simulations of the Mid-Holocene and Last Glacial Maximum Part 2: feedbacks with emphasis on the location of the ITCZ and mid- and high latitudes heat budget, Clim. Past, 3, 279-296, doi:10.5194/cp-3-279-2007, 2007. 
Braconnot, P., Marzin, C., Grégoire, L., Mosquet, E., and Marti, O.: Monsoon response to changes in Earth's orbital parameters: comparisons between simulations of the Eemian and of the Holocene, Clim. Past, 4, 281-294, doi:10.5194/cp-4-281-2008, 2008.

Camberlin, P.: Rainfall Anomalies in the Source Region of the Nile and Their Connection with the Indian Summer Monsoon, J. Climate, 10, 1380-1392, 1997.

Clemens, S., Prell, W., Murray, D., Shimmield, G. and Weedon, G.: Forcing mechanisms of the Indian Ocean monsoon, Nature, 353(6346), 720-725, 1991.

Clemens, S., Prell, W. and Sun, Y.: Orbital-scale timing and mechanisms driving Indo-Asian summer monsoons: Reinterpreting speleothem $\delta^{18} \mathrm{O}$, Paleoceanography, 25, PA4207, doi:10.1029/2010PA001926, 2010.

Clemens, S. C.: Dust response to seasonal atmospheric forcing: Proxy evaluation and calibration, Paleoceanography, 13, 471490, 1998.

Clemens, S. C. and Prell, W. L.: A 350,000 year summer-monsoon multi-proxy stack from the Owen Ridge, Northern Arabian Sea, Mar. Geol., 201, 35-51, 2003.

COHMAP members: Climatic changes of the last 18,000 years: Observations and model simulations, Science, 241, 365-379, 1988.

Conan, S. and Brummer, G.: Fluxes of planktic foraminifera in response to monsoonal upwelling on the Somalia Basin margin, Deep-Sea Res. Pt. II, 47(9-11), 2207-2227, 2000.

Cullen, J. and Prell, W.: Planktonic foraminifera of the northern Indian Ocean: distribution and preservation in surface sediments, Mar. Micropaleontol., 9, 1-52, 1984.

Curry, W., Ostermann, D., Guptha, M., and Ittekkot, V.: Foraminiferal production and monsoonal upwelling in the Arabian Sea: evidence from sediment traps, Geol. Soc. Lond. Spec. Publ., 64(1), 93, 1992.

Duplessy, J. C., Arnold, M., Maurice, P., Bard, E., Duprat, J., and Moyes, J.: Direct dating of the oxygen-isotope record of the last deglaciation by ${ }^{14} \mathrm{C}$ accelerator mass spectrometry, Nature, 320(6060), 350-352, 1986.

Durand, F., Shankar, D., Boyer de Montegut, C., Shenoi, S. S. C., Blanke, B. and Madec, G.: Modeling the barrier-layer formation in the southeastern Arabian Sea, J. Climate, 20(10), 2109-2120, 2007.

Emeis, K., Anderson, D., Doose, H., Kroon, D., and Schulz-Bull, D.: Sea surface temperatures and history of monsoon upwelling in the northwest arabian sea during the last 500,000 years, Quaternary Res., 43, 355-361, 1995.

Fichefet, T. and Morales Maqueda, M. A.: Sensitivity of a global sea ice model to the treatment of ice thermodynamics and dynamics, J. Geophys. Res., 102(C6), 12609-12646, doi:10.1029/97JC00480, 1997.

Fleitmann, D., Burns, S. J., Mudelsee, M., Neff, U., Kramers, J., Mangini, A., and Matter, A.: Holocene forcing of the Indian monsoon recorded in a stalagmite from Southern Oman, Science, 300(5626), 1737-1739, 2003.

Gehlen, M., Gangst $\varnothing$, R., Schneider, B., Bopp, L., Aumont, O., and Ethe, C.: The fate of pelagic $\mathrm{CaCO}_{3}$ production in a high $\mathrm{CO}_{2}$ ocean: a model study, Biogeosciences, 4, 505-519, doi:10.5194/bg-4-505-2007, 2007.
Gupta, A. K., Anderson, D. M., and Overpeck, J. T.: Abrupt changes in the Asian southwest monsoon during the Holocene and their links to the North Atlantic Ocean, Nature, 421(6921), 354-357, 2003.

Honjo, S.: Fluxes of particles to the interior of the open oceans, in: Particle Flux In The Ocean, edited by: Ittekkot, V., Schäfer, P., Honjo, S., and Depetris, P., John Wiley, New York, 91-145, 1996.

Hourdin, F., Musat, I., Bony, S., Braconnot, P., Codron, F., Dufresne, J.-L., Fairhead, L., Filiberti, M.-A., Friedlingstein, P., Grandpeix, J.-Y., Krinner, G., LeVan, P., Li, Z.-X., and Lott, F.: The LMDZ4 general circulation model: climate performance and sensitivity to parametrized physics with emphasis on tropical convection, Clim. Dynam., 27(7-8), 787-813, doi:10.1007/s00382-006-0158-0, 2006.

Ihara, C., Kushnir1, Y., Cane1, M. A., and De La Peña, V. H.: Indian summer monsoon rainfall and its link with ENSO and Indian Ocean climate indices, Int. J. Climatol., 27(2), 179-187, 2007.

Ivanochko, T., Ganeshram, R. J., Brummer, G.-J. A., Ganssen, G., Jung, S. J. A., Moreton, S. G., and Kroon, D.: Variations in tropical convection as an amplifier of global climate change at the millennial scale, Earth. Planet. Sc. Lett., 235, 302-314, 2005.

Joussaume, S., Taylor, K. E., Braconnot, P., Mitchell, F. B., Kutzbach, E., Harrison, S. P., Prentice, I. C., Broccoli, A. J., AbeOuchi, A., Bartlein, J., Bonfils, C., Dong, B., Guiot, J., Henerich, K., Hewitt, C. D., Jolly, D., Kim, J. W., Kislov, A., Kitoh, A., Loutre, M. F., Masson, V., McAvaney, B., McFarlane, N., de Noblet, N., Peltier, W. R., Peterschmitt, J. Y., Pollard, D., Rind, D., Royer, F., Schlesinger, M. E., Syktus, J., Thompson, S., Valdes, P., Vettoretti, G., Webb, R. S., and Wyput, U.: Monsoon changes for 6000 years ago: Results of 18 simulations from the Paleoclimate Modeling Intercomparison Project (PMIP), Geophys. Res. Lett., 26(7), 859-862, doi:10.1029/1999GL900126, 1999.

Koné, V., Aumont, O., Levy, M., and Resplandy, L.: Physical and biogeochemical controls of the phytoplankton seasonal cycle in the Indian Ocean: a modeling study, in: Indian Ocean Biogeochemical Processes and Ecological Variability, Geophys. Monogr. Ser., 185, 147-166, doi:10.1029/2008GM000700, 2009.

Krinner, G., Viovy, N., de Noblet-Ducoudre, N., Ogée, J., Polcher, J., Friedlingstein, P., Ciais, P., Sitch, S., and Prentice, C. A dynamic global vegetation model for studies of the coupled atmosphere-biosphere system, Global Biogeochem. Cy., 19, GB1015, doi:10.1029/2003GB002199, 2005.

Kumar, K. K., Rajagopalan, B., Hoerling, M., Bates, G., and Cane, M.: Unraveling the Mystery of Indian Monsoon Failure During El Niño, Science, 314(5796), 115-119, doi:10.1126/science.1131152, 2006.

Lee, C., Jones, B., Brink, K., and Fischer, A.: The upper-ocean response to monsoonal forcing in the Arabian Sea: seasonal and spatial variability, Deep-Sea Res. Pt. II, 47(7), 1177-1226, 2000.

Levitus, S.: Climatological Atlas of the World Ocean, NOAA Professional Paper, 13, 191, 1982.

Levy, M., Shankar, D., Andre, J. M., Shenoi, S. S. C., Durand, F., DeBoyer Montegut, C.: Basin-wide seasonal evolution of the Indian Ocean's phytoplankton blooms, J. Geophys. Res., 112, C12014, doi:10.1029/2007JC004090, 2007. 
Liu, Z., Otto-Bliesner, B., Kutzbach, J., Li, L., and Shields, C.: Coupled Climate Simulation of the Evolution of Global Monsoons in the Holocene, J. Climate, 16, 2472-2490, 2003.

Lombard, F., Labeyrie, L., Michel, E., Bopp, L., Cortijo, E., Retailleau, S., Howa, H., and Jorissen, F.: Modelling planktic foraminifer growth and distribution using an ecophysiological multi-species approach, Biogeosciences, 8, 853-873, doi:10.5194/bg-8-853-2011, 2011.

Madec, G., Delecluse, P., Imbard, M., and Lévy, C.: Ocean General Circulation Model reference manual, Notes du Pole de Modélisation de l'Institut Pierre-Simon Laplace, available from: http://www.nemo-ocean.eu/Media/Files/Doc_OPA8.1, last access: July 2011, 11, 91 pp., 1998.

Mall, R. K., Singh, R., Gupta, A., Srinivasan, G., and Rathore, L. S.: Impact of Climate Change on Indian Agriculture: A Review, Climatic Change, 78(2-4), 445-478, doi:10.1007/s10584-0059042-x, 2006.

Marti, O., Braconnot, P., Dufresne, J.-L., Bellier, J., Benshila, R., Bony, S., Brockmann, P., Cadule, P., Caubel, A., Codron, F., de Noblet, N., Denvil, S., Fairhead, L., Fichefet, T., Foujols, M.-A., Friedlingstein, P., Goosse, H., Grandpeix, J.-Y., Guilyardi, E., Hourdin, F., Idelkadi, A., Kageyama, M., Krinner, G., Lévy, C., Madec, G., Mignot, J., Musat, I., Swingedouw, D., and Talandier, C.: Key features of the IPSL ocean atmosphere model, and its sensitivity to atmospheric resolution, Clim. Dynam., 34, 1-26, doi:10.1007/s00382-009-0640-6, 2010.

Marzin, C. and Braconnot, P.: Variations of Indian and African monsoons induced by insolation changes at 6 and $9.5 \mathrm{kyr} \mathrm{BP}$, Clim. Dynam., 33(2-3), 215-231, doi:10.1007/s00382-0090538-3, 2009a.

Marzin, C. and Braconnot, P.: The role of the ocean feedback on Asian and Africa monsoon variations at $6 \mathrm{kyr}$ and $9.5 \mathrm{kyr} \mathrm{BP}, \mathrm{C}$. R. Geosci., 341, 643-655, 2009b.

Masson, S., Luo, J., Madec, G., Vialard, J., Durand, F., Gualdi, S., Guilyardi, E., Behera, S., Delecluse, P., Navarra, A., and Yamagata, T.: Impact of barrier layer on winter-spring variability of the southeastern Arabian Sea, Geophys. Res. Lett., 32, L07703, doi:10.1029/2004GL021980, 2005.

Mléneck Vautravers, M.: Sédimentation et dissolution des carbonates biogéniques aux moyennes latitudes Nord et Sud, Approche quantitative et relations avec les paléocirculations océaniques des derniers 150000 ans, $\mathrm{PhD}$ thesis, Université Bordeaux I, 277 pp., 1997.

Mooley, D. A., Parthasarathy, B., Sontakke, N. A., and Munot, A. A.: Annual rain-water over India, its variability and impact on the economy, Int. J. Climatol., 1(2), 167-186, 1981.

Naidu, P. D.: Distribution of upwelling index planktonic foraminifera in the sediments of the western continental margin of India, Oceanol. Acta, 13, 327-333, 1990.

Naidu, P. D.: Distribution patterns of recent planktonic foraminifera in surface sediments of the western continental margin of India, Mar. Geol., 110, 403-418, 1993.

Naidu, P. D. and Malmgren, B. A.: A 2,200 years periodicity in the Asian monsoon system, Geophys. Res. Lett., 22(17), 2361-2364, 1995.

Naidu, P. D. and Malmgren, B. A.: A high-resolution record of late quaternary upwelling along the Oman Margin, Arabian Sea based on planktonic foraminifera, Paleoceanography, 11(1), 129-140, 1996.
Ohgaito, R. and Abe-Ouchi, A.: The role of ocean thermodynamics and dynamics in Asian summer monsoon changes during the Mid-Holocene, Clim. Dynam. 29(1), 39-50, 2007.

Ortiz, J. D., Mix, A. C., and Collier, R. W.: Environmental control of living symbiotic and asymbiotic foraminifera of the California Current, Paleoceanography, 10, 987-1009, 1995.

Overpeck, J., Anderson, D., Trumbore, S., and Prell, W.: The southwest Indian Monsoon over the last 18000 years, Clim. Dynam., 12, 213-225, 1996.

Paillard, D., Labeyrie, L., and Yiou, P.: Macintosch program performs timeseries analysis, analyseries software now available at: http://www.lsce.ipsl.fr/logiciels/index.php, last access: July 2011, EOS Trans. AGU, 77, 379, 1996.

Prell, W. and Curry, W.: Faunal and isotopic indices of monsoonal upwelling: western Arabian Sea, Oceanol. Acta, 4(1), 91-98, 1981.

Prell, W. L. and Kutzbach, J. E.: Monsoon variability over the past 150000 years, J. Geophys. Res., 92, 8411-8425, 1987.

Prell, W. L. and Kutzbach, J. E.: Sensitivity of the Indian monsoon to forcing parameters and implications for its evolution, Nature, 360, 647-652, 1992.

Rao, R. R. and Sivakumar, R.: On the possible mechanisms of the evolution of a mini-warm pool during the pre-summer monsoon season and the genesis of onset vortex in the south-eastern Arabian Sea, Q. J. Roy. Meteorol. Soc., 125, 787-809, 1999.

Rao, R. R., Molinari, R. L., and Festa, J. F.: Evolution of the Climatological Near-Surface Thermal Structure of the Tropical Indian Ocean, 1. Description of Mean Monthly Mixed Layer Depth, and Sea Surface Temperature, Surface Current, and Surface Meteorological Fields, J. Geophys. Res., 94, 10801-10815, 1989.

Saha, K. R., Mooley, D. A., and Saha, S.: The Indian monsoon and its economic impact, GeoJournal, 3(2), 171-178, doi:10.1007/BF00257706, 1979.

Sautter, L. R. and Thunell, R. C.: Seasonal succession of planktonic foraminifera: results from a four-year time-series sediment trap experiment in the northeast Pacific, J. Foramin. Res., 19, 253 267, 1989.

Schott, F. A. and McCreary Jr., J. P.: The monsoon circulation of the Indian Ocean, Prog. Oceanogr., 51(1), 1-123, 2001.

Sharma, G. S.: Upwelling off the southwest coast of India, Indian J. Mar. Sci., 7, 209-218, 1978.

Shetye, S. R., Gouveia, A. D., Shenoi, S. S. C., Sundar, D., Michael, G. S., Almeida, A. M., and Santanam, K.: Hydrography and circulation off the west coast of India during the southwest monsoon 1987, J. Mar. Res., 48, 359-378, 1990.

Stuiver, M. and Braziunas, T. F.: Modeling atmospheric $\mathrm{C}^{-14}$ influences and $\mathrm{C}^{-14}$ ages of marine Samples to $10,000 \mathrm{Bc}$, Radiocarbon, 35(1), 137-189, 1993.

Stuiver, M., Reimer, P. J., Bard, E., Beck, J. W., Burr, G. S., Highen, K. A., Kromer, B., McCormac, G., Van der Plicht, J., and Spurk, M.: INTCAL98 radiocarbon age calibration, 24,000-0 cal BP, Radiocarbon, 40(3), 1041-1083, 1998.

Terray, L., Thual, O., Belamari, S. , Déqué, M., Dandin, P., Delecluse, P., and Levy, C.: Climatology and interannual variability simulated by the ARPEGE-OPA coupled model, Clim. Dynam., 11(8), 487-505, doi:10.1007/BF00207197, 1995.

Watkins, J. M. and Mix, A. C.: Testing the effects of tropical temperature,productivity, and mixed-layer depth on foraminiferal transfer functions, Paleoceanography, 13, 96-105, 1998. 
Zaric, S., Donner, B., Fischer, G., Mulitza, S., and Wefer, G.: Sensitivity of planktic foraminifera to sea surface temperature and export production as derived from sediment trap data, Mar. Micropaleontol., 55(1-2), 75-105, 2005.

Zhang, R. and Delworth, T. L.: Impact of Atlantic multidecadal oscillations on India/Sahel rainfall and Atlantic hurricanes, Geophys. Res. Lett., 33, L17712, doi:10.1029/2006GL026267, 2006.
Zhao, Y., Braconnot, P., Marti, O., Harrison, S. P., Hewitt, C., Kitoh, A., Liu, Z., Mikolajewicz, U., Otto-Bliesner, B., and Weber, S. L.: A multi-model analysis of the rôle of the ocean on the African and Indian monsoon during the mid-Holocene, Clim. Dynam., 25(7-8), 777-800, doi:10.1007/s00382-005-0075-7, 2005. 